\title{
Efektivitas Konseling Puisi sebagai Media Bimbingan dan Konseling dalam Meningkatkan Rasa Percaya Diri Peserta Didik Kelas VII SMPN 24 Bandar Lampung Tahun Ajaran 2015/2016
}

\author{
Laila Maharani, Muhammad Mansur
}

Dosen Fakultas Tarbiyah dan Keguruan, IAIN Raden Intan Lampung

Diterima: 27 April 2016. Disetujui: 12 Agustus 2016. Dipublikasikan: Nopember 2016

\begin{abstract}
Abstrak: Percaya diri merupakan kunci motivasi diri. Setiap individu akan membutuhkan kepercayaan diri setiap harinya dalam berbagai hal, termasuk peserta didik dalam mengikuti proses belajar di sekolah. Tingkat kepercayaan diri yang baik memudahkan pengambilan keputusan dan melancarkan jalan untuk mendapatkan teman, membangun hubungan, dan membantu individu lain dalam membangun kesuksesan. Tujuan dari penelitian ini yaitu untuk mengetahui apakah konseling puisi sebagai media bimbingan dan konseling efektif dalam meningkatkan rasa percaya diri peserta didik kelas VII SMPN 24 Bandar Lampung tahun ajaran 2015/2016. Jenis penelitian yang dilaksanakan adalah Quasi Eksperimen dengan desain penelitian Nonequivalent Control Group Design. Sampel penelitian ini adalah peserta didik kelas VII SMPN 24 Bandar Lampung yang tidak tampil saat perlombaan membaca puisi dan stand up comedy yang berjumlah 20 peserta didik, yang kemudian diberikan angket percaya diri yang telah diuji validitas. keseluruhan peserra didik tersebt berada pada kategori percaya diri rendah. Berdasarkan hasil penelitian, diketahui bahwa terdapat peningkatan percaya diri peserta didik setelah melaksanakan layanan konseling puisi sebagai media bimbingan dan konseling dengan diperoleh df $=18$ kemudian dibandingkan dengan tabel 0.05 , maka tabel $=2.101$ dan nilai thitung lebih besar dari tabel, (3.939 $\geq 2.101$ ). Jadi dapat disimpulkan bahwa layanan bimbingan kelompok dengan konseling puisi sebagai media bimbingan dan konseling dapat meningkatkan rasa percaya diri peserta didik kelas VII SMPN 24 Bandar Lampung Tahun Ajaran 2015/2016.
\end{abstract}

Kata Kunci: Konseling Puisi; Media Bimbingan dan Konseling, Percaya Diri

\section{Pendahuluan}

Media bimbingan dan konseling adalah segala sesuatu yang dapat digunakan untuk menyalurkan pesan bimbingan dan konseling yang dapat merangsang pikiran, perasaan, perhatian, dan kemauan peserta didik/konseli untuk memahami diri, mengarahkan diri, mengambil keputusan, serta memecahkan masalah yang dihadapMedia bimbingan dan konseling selalu terdiri atas dua unsur penting, yaitu unsur peralatan atau perangkat keras (hardware) dan unsur pesan yang dibawanya (message/software). Dengan demikian perlu dipahami, media bimbingan dan konseling memerlukan peralatan untuk menyajikan pesan, namun yang terpenting bukanlah peralatan itu, tetapi pesan atau informasi bimbingan dan konseling tersebut. Dengan demikian, dapat disimpulkan bahwa: (1) media bimbingan dan konseling merupakan wadah dari pesan; (2) materi yang ingin disampaikan adalah pesan bimbingan dan konseling; dan (3) tujuan yang ingin dicapai ialah perkembangan peserta didik secara optimal.

Sementara itu, dalam usaha memanfaatkan media sebagai alat bantu, Edgar Dale mengklasifikasikan menurut tingkatannya dari yang paling kongkrit ke yang paling abstrak. Susunannya adalah sebagai berikut: (1) pengalaman langsung; (2) pengalaman tiruan; (3) pengalaman dramatisasi; (4) percontohan; (5) darmawisata; (6) pameran museum; (7) televisi; (8) gambar hidup; (9) gambar tetap, rekaman dan radio; (10) lambang visual; dan (11) lambang verbal. Klasifikasi ini dinamakan dengan kerucutpengalaman (cone of experience) dengan maksud menentukan alat bantu yang paling sesuai untuk pengalaman belajar maupun pengalaman bimbingan dan konseling. Alat bantu yang digunakan dalam penelitian ini lebih menekankan pada penggunaan puisi. 
Puisi adalah seni tertulis di mana bahasa digunakan untuk kualitas estetiknya untuk tambahan, atau selain arti semantiknya. Untuk memberikan gambaran yang jelas, untuk menimbulkan suasana, untuk membuat lebih hidup dan menarik, dalam puisi penyair juga sering menggunakan gambaran angan. Gambaran angan dalam puisi ini disebut citraan (imagery). Citraan atau pengimajian adalah gambar-gambar dalam pikiran, atau gambaran angan si penyair. Setiap gambar pikiran disebut citra atau imaji (image). Gambaran pikiran ini adalah sebuah efek dalam pikiran yang sangat menyerupai gambaran yang dihasilkan oleh penangkapan kita terhadap sebuah objek yang dapat dilihat oleh mata (indera penglihatan). Citraan tidak membuat kesan baru dalam pikiran

Alasan lain mengapa citraan dalam puisi dapat digunakan dalam konseling menurut Samuel T. Gladding antara lain adalah:

"especially guide imagery, is that it is valuable for counselors and clients in "developing cognitive flexibility". it teaches people how to use their imagination as a tool for stimulating creativity and for loosening the tight grip of the so-called normal waking state of consciousness."

Menurut pendapat tersebut, jelas bahwasanya dalam memandu citra, sangat berguna bagi konselor dan klien dalam "mengembangkan fleksibilitas kognitif ". Mengajarkan kita bagaimana menggunakan imajinasi sebagai alat untuk merangsang kreativitas dan untuk melonggarkan cengkeraman ketat yang disebut keadaan membangun kesadaran normal. Hasil cipta kreatif yang menciptakan inovasi baru dalam bimbingan dan konseling adalah konseling puisi.

Peneliti menggunakan antologi puisi yang telah diciptakan dalam sebuah karya besar milik Dra. Laila Maharani, M. Pd yang sudah dicetak dalam bentuk buku yang peneliti dapatkan dari hasil seminar dan workshop nasional media BK dan pengembangan pribadi dengan tema "Pengembangan Diri Kreatif Melalui Konseling Puisi, Hipno Konseling, Cyber Konseling, dan Konseling Kesehatan Mental" yang diselenggarakan oleh Prodi Bimbingan dan Konseling IAIN Raden Intan Lampung. Sementara itu, puisi yang digunakan dalam penelitian ini terbagi kedalam tiga kelompok, yaitu: (1) kelompok puisi komponen personal, yang lebih menekankan pada aspek pemahaman diri dan pengubahan sikap; (2) kelompok puisi komponen sosial, yang lebih menekankan pada dukungan sosial; dan (3) kelompok puisi komponen nilai, yang terfokus pada makna hidup, keikatan diri, serta kegiatan terarah.

Sebagai media kreatif, puisi dapat digunakan sebagai pesan dalam media bimbingan dan konseling dan puisi dapat menjadi alat bantu yang paling sesuai untuk pengalaman belajar maupun pengalaman bimbingan dan konseling. Selanjutnya, puisi tersebut di demonstrasikan dan ada beberapa keunggulan yang bisa diperoleh dengan teknik demonstrasi berpuisi sebagai media bimbingan dan konseling. Antara lain dapat menyalurkan ekspresi konseli kedalam kegiatan yang menyenangkan, membantu menghilangkan perasaan malu, keseganan, dan kesedihan pada konseli, dan meningkatkan rasa kesadaran diri dan rasa percaya diri konseli. Dengan memperhatikan kerucut pengalaman Edgar Dale tersebut, maka puisi sebagai pesan dalam media bimbingan dan konseling berada pada tataran simbol (lambang verbal) dalam kerucut pengalaman (cone experience). Dalam penggunaan media, guru bimbingan dan konseling tidak memerlukan jam khusus, karena penggunaan media bimbingan dan konseling bisa dilaksanakan di luar ruangan dan dapat dilaksanakan saat jam pelajaran yang kosong dan ketika ada waktu luang. Hal tersebut sesuai dengan pernyataan mengenai pelaksanaan program dari bimbingan dan konseling seperti berikut ini:

"kegiatan tatap muka dengan peserta didik untuk menyelenggarakan layanan orientasi, bimbingan dan konseling perorangan, bimbingan kelompok, bimbingan dan konseling kelompok, dan mediasi, serta kegiatan lainnya dapat dilaksanakan di luar kelas. Satu kali kegiatan layanan/pendukung bimbingan dan konseling di luar kelas/di luar jam pembelajaran ekuivalen dengan 2 (dua) jam pembelajaran tatap muka dalam kelas. Kegiatan pelayanan 
bimbingan dan konseling di luar jam pembelajaran sekolah maksimum 50\% dari seluruh kegiatan pelayanan bimbingan dan konseling, diketahui dan dilaporkan kepada pimpinan sekolah. Kegiatan pelayanan bimbingan dan konseling dicatat dalam laporan pelaksanaan program (LAPELPROG). Volume dan waktu untuk pelaksanaan kegiatan pelayanan bimbingan dan konseling di dalam kelas dan di luar kelas setiap minggu diatur oleh konselor dengan persetujuan pimpinan sekolah. Program pelayanan bimbingan dan konseling pada masing-masing satuan sekolah dikelola dengan memperhatikan keseimbangan dan kesinambungan program antarkelas dan antarjenjang kelas, dan mensinkronisasikan program pelayanan bimbingan dan konseling dengan kegiatan pembelajaran mata pelajaran dan kegiatan ekstra kurikuler, serta mengefektifkan dan mengefisienkan penggunaan fasilitas sekolah."

Berdasarkan pernyataan tersebut, jelas bahwasanya pelaksanaan kegiatan dari bimbingan dan konseling tidak harus selalu berada di dalam ruangan, melainkan bisa dilaksanakan di luar ruangan dan kegiatan tersebut berbanding dengan 2 (dua) jam pembelajaran tatap muka dalam kelas. Namun semua kegiatan harus berdasarkan persetujuan dari kepala sekolah dan bidang lainnya, karena bimbingan dan konseling memiliki keterkaitan dengan bidang-bidang lainnya agar pendidikan di sekolah berjalan dengan sebaik-baiknya untuk memenuhi kebutuhan peserta didik secara optimal dalam proses perkembangannya.

Strategi berikutnya dalam melaksanakan program bimbingan dan konseling adalah penggunaan sebuah layanan. Layanan yang digunakan dalam penelitian kali ini adalah bimbingan kelompok. Bimbingan kelompok dimaksudkan untuk mencegah berkembangnya masalah atau kesulitan pada diri peserta didik. Untuk memaksimalkan pelaksanaan bimbingan kelompok, peneliti memanfaatkan media bimbingan dan konseling dengan teknik berpuisi dalam memberikan perlakuan kepada peserta didik.

Berdasarkan latar belakang yang telah dipaparkan, maka peneliti tertarik untuk melakukan penelitian dengan judul "Efektivitas Konseling Puisi Sebagai Media Bimbingan dan Konseling Dalam Meningkatkan Rasa Percaya Diri Peserta Didik Kelas VII SMPN 24 Bandar Lampung Tahun Ajaran 2015/2016".

\section{A. Konseling Puisi Sebagai Media Bimbingan dan Konseling}

1. Pengertian Konseling Puisi

Konseling puisi adalah hasil cipta kreatif pada sebuah layanan konseling yang memanfaatkan puisi sebagai media dalam bimbingan dan konseling. Konseling puisi juga merupakan inovasi baru dalam dunia bimbingan dan konseling, dimana puisi dijadikan sebagai salah satu alternatif media bimbingan dan konseling

2. Pengertian Media Bimbingan dan Konseling

Kata "media" berasal dari Bahasa latin "medius" yang secara harfiah berarti tengah, perantara, atau pengantar. Gerlach dan Ely mengatakan bahwa media apabila dipahami secara garis besar adalah manusia, materi, atau kejadian yang membangun kondisi yang membuat peserta didik mampu memperoleh pengetahuan, keterampilan, atau sikap. Dalam pengertian ini, guru, buku teks, dan lingkungan sekolah merupakan media. Secara lebih khusus, pengertian media dalam proses belajar mengajar cenderung diartikan sebagai alat-alat grafis, photografis, atau elektronis untuk menangkap, memproses, dan menyusun kembali informasi visual atau verbal.

Sementara itu, menurut Heinich, media merupakan alat saluran komunikasi. Media berasal dari bahasa latin dan merupakan bentuk jamak dari kata "medium" yang secara harfiah berarti "perantara" yaitu perantara sumber pesan (a source) dengan penerima pesan (a receiver). Heinich mencontohkan media seperti film, televisi, diagram, bahan tercetak, komputer, dan instruktur. Dan contoh media tersebut dapat dipertimbangkan sebagai media bimbingan dan konseling jika membawa pesan-pesan (messages) dalam rangka mencapai tujuan bimbingan dan konseling Berdasarkan pemaparan tersebut, maka dapat ditarik 
kesimpulan bahwasanya media bimbingan dan konseling adalah segala sesuatu yang dapat digunakan untuk menyalurkan pesan bimbingan dan konseling yang dapat merangsang pikiran, perasaan, perhatian, dan kemauan peserta didik/konseli untuk memahami diri, mengarahkan diri, mengambil keputusan, serta memecahkan masalah yang dihadapi.

Media bimbingan dan konseling selalu terdiri atas dua unsur penting, yaitu unsur peralatan atau perangkat keras (hardware) dan unsur pesan yang dibawanya (message/software). Dengan demikian perlu difahami, media bimbingan dan konseling memerlukan peralatan untuk menyajikan pesan, namun yang terpenting bukanlah peralatan itu, tetapi pesan atau informasi bimbingan dan konseling tersebut. Software sebagai perangkat lunak adalah informasi atau bahan bimbingan dan konseling itu sendiri yang akan disampaikan kepada peserta didik/konseli, sedangkan hardware adalah sarana atau peralatan yang digunakan untuk menyajikan pesan bimbingan dan konseling tersebut. Dengan demikian, dapat disimpulkan bahwa:

1. media bimbingan dan konseling merupakan wadah dari pesan;

2. materi yang ingin disampaikan adalah pesan bimbingan dan konseling; dan

3. tujuan yang ingin dicapai ialah perkembangan peserta didik secara optimal.

\section{B. Rasa Percaya Diri Pada Peserta Didik}

1. Hakikat Percaya Diri

Percaya diri pada dasarnya merupakan suatu keyakinan untuk menjalani kehidupan, mempertimbangkan pilihan dan membuat keputusan sendiri pada diri sendiri bahwa ia mampu untuk melakukan sesuatu. Artinya keyakinan dan percaya diri hanya timbul pada saat seseorang mengerjakan sesuatu yang memang mampu dilakukannya. Pada dasarnya seseorang merasa puas pada dirinya sendiri hanya pada saat melakukan suatu kegiatan, pekerjaan atau menyalurkan kemampuannya. Banyak hal yang dapat dilakukan dan banyak juga kemampuan yang dapat dikuasai seseorang dalam hidupnya. Tetapi jika hanya percaya diri pada hal-hal yang berkaitan dengan apa yang dilakukan dan beberapa keterampilan tertentu saja yang dikuasai Percaya diri adalah keyakinan bahwa orang mempunyai kemampuan untuk melakukan sesuatu untuk mencapai tujuan tertentu. Percaya diri juga merupakan keyakinan orang atas kemampuannya untuk menghasilkan level-level pelaksanaan yang memengaruhi kejadiankejadian yang memengaruhi kehidupan mereka. Percaya diri adalah keyakinan bahwa orang mempunyai kemampuan untuk memutuskan jalannya suatu tindakan yang dituntut untuk mengurusi situasi-situasi yang dihadapi.

Dengan percaya diri, kita sadar akan eksistensi diri, akan inti kepribadian kita yang tidak dapat diubah dan yang berlangsung selama hidup kita betapapun bervariasinya lingkungan kita, dan bagaimanapun berubahnya pendapat dan perasaan orang lain. Dalam inti inilah realitas dibalik kata "Aku", dan dari realitas itulah didasarkan pendapat kita tentang identitas kita. Jika kita tidak memiliki keyakinan pada kelangsungan diri kita, perasaan kita akan identitas itu akan terancam dan kita menjadi tergantung pada orang lain yang persetujuannya menjadi dasar perasaan kita akan identitas. Percaya diri itu penting dalam hubungannya dengan percaya pada orang lain. Hanya orang yang memiliki kepercayaan pada dirinyalah yang mampu untuk percaya pada orang lain. Hanya dialah yang dapat yakin bahwa dia akan tetap sama di masa yang akan datang sebagaimana dia hari ini. Dengan demikian, ia akan merasakan dan bertindak sebagaimana dia harapkan sekarang.

\section{Karakteristik Individu Yang Percaya Diri}

Beberapa ciri atau karakteristik individu yang mempunyai rasa percaya diri yang proporsional, di antaranya adalah sebagai berikut: 
Menurut Syaifullah dalam Dewi, menyatakan "ciri-ciri pribadi seseorang yang memiliki sikap percaya diri diantaranya adalah:

a) tidak mudah mengalami rasa putus asa. pribadi yang percaya diri akan selalu antusias dalam melakukan suatu tindakan memiliki tekad, tekun dan pantang menyerah;

b) bisa menghargai dan usahanya sendiri;

c) mengutamakan usaha sendiri tidak tergantung dengan orang lain

d) berani menyampaikan pendapat. Berpendapat merupakan suatu hak yang dimiliki oleh setiap orang, tetapi tidak semua orang memiliki keberanian untuk menyampaikan pendapat, rasa takut dan khawatir untuk berbicara merupakan salah satu ciri-ciri sikap tidak percaya diri dengan kemampuannya;

e) tanggung jawab dengan tugas- tugasnya. Pribadi yang percaya diri akan selalu memiliki taggung jawab pada dirinya sendiri yaitu selalu mengerjakan apa yang menjadi tugas dalam menjalankan suatu tindakan. Di kerjakan dengan tekun dan rajin;

f) memiliki cita-cita untuk meraih prestasi; dan

g) selalu bersosialisasi dan berinteraksi antar sesama".

Indikator rasa percaya diri dapat dilihat dari beberapa aspek berikut ini: (1) memiliki kemauan dan usaha; (2) memiliki sikap optimis; (3) mandiri; (4) tidak mudah menyerah; (5) mampu menyesuaikan diri; (6) memiliki dan memanfaatkan kelebihan; dan (7) memiliki mental dan fisik yang menunjang.

\section{Layanan Bimbingan Kelompok}

Strategi lain dalam melaksanakan layanan dasar bimbingan adalah bimbingan kelompok. Bimbingan kelompok dimaksudkan untuk mencegah berkembangnya masalah atau kesulitan pada peserta didik. Isi kegiatan bimbingan kelompok terdiri atas penyampaian informasi yang berkenaan dengan masalah pendidikan, pekerjaan, pribadi, danmasalah sosial yang tidak disajikan dalam bentuk pelajaran.

Penataan bimbingan kelompok pada umumnya berbentuk kelas yang beranggotakan 15 sampai 20 orang. Informasi yang diberikan dalam bimbingan kelompok itu terutama dimaksudkan untuk memperbaiki dan mengembangkan pemahaman diri dan pemahaman mengenai orang lain, sedangkan perubahan sikap merupakan tujuan yang tidak langsung. Kegiatan bimbingan kelompok biasanya dipimpin oleh seorang guru bimbingan konseling. Kegiatan bimbingan kelompok pada umumnya menggunakan prinsip dan proses dinamika kelompok, seperti dalam kegiatan sosiodrama, diskusi panel, dan teknik lainnya yang berkaitan dengan kegiatan kelompok. Penyelenggaraan bimbingan kelompok memerlukan persiapan dan praktik pelaksanaan kegiatan yang memadai, dari langkah awal sampai dengan langkah evaluasi dan tindak lanjutnya.

\section{Metode Penelitian}

Metode yang digunakan dalam penelitian ini adalah penelitian quasi experimental, yaitu metode penelitian yang menguji hipotesis berbentuk sebab akibat melalui adanya perlakuan dan menguji perubahan yang diakibatkan oleh perlakuan tersebut. Alasan peneliti menggunakan penelitian ini karena dalam rancangan metode quasi experimental terdapat kelompok kontrol dan kelompok eksperimen. 


\section{Hasil dan Pembahasan}

a. Gambaran Percaya diri Pada Indikator Kemauan dan Usaha

Tabel 1. Gambaran Percaya Diri Pada Indikator Kemauan dan Usaha

\begin{tabular}{|c|c|c|c|c|}
\hline Hasil & Interval & Frekuensi & Persentase & \multirow{2}{*}{ Presentase } \\
\hline Sangat Tinggi & $\geq 16.8-20$ & 1 & $3.70 \%$ & \\
\cline { 1 - 4 } Tinggi & $\geq 13.6-16.8$ & 7 & $25.92 \%$ & \\
\cline { 1 - 3 } Sedang & $\geq 10.4-13.6$ & 4 & $14.82 \%$ & \multirow{2}{*}{$53.15 \%$} \\
\cline { 1 - 3 } Rendah & $\geq 7.2-10.4$ & 13 & $48.14 \%$ & \\
\cline { 1 - 3 } Sangat Rendah & $\geq 4-7.2$ & 2 & $7.40 \%$ & \\
\hline
\end{tabular}

Berdasarkan tabel 1 persentase pada indikator kemauan dan usaha dalam percaya diri peserta didik sebagian besar berada pada kategori rendah, sedangkan peserta didik lainnya berada pada kategori sangat tinggi, tinggi, sedang, dan sangat rendah. Hal ini ditandai dengan sikap peserta didik yang masih memiliki pendirian yang mudah berubah-ubah.

b. Gambaran Percaya Diri Pada Indikator Optimis

Hasil penelitian menunjukkan gambaran percaya diri peserta didik pada indikator optimis berada pada kategori sangat tinggi sebanyak 1 peserta didik (3.70\%), pada kategori tinggi sebanyak 7 peserta didik (25.92\%), pada kategori sedang sebanyak 4 peserta didik (14.82\%),pada kategori rendah sebanyak 13 peserta didik (48.14\%) dan pada kategori sangat rendah sebanyak 2 peserta didik (7.40\%). Secara rinci disajikan pada Tabel 12.

Tabel 2. Gambaran Percaya Diri Pada Indikator Optimis

\begin{tabular}{|c|c|c|c|c|}
\hline Kategori & Interval & Frekuensi & Persentase & Presentase \\
\hline Sangat Tinggi & $\geq 16.8-20$ & 1 & $3.70 \%$ & \\
\hline Tinggi & $\geq 13.6-16.8$ & 6 & $22.22 \%$ & \\
\hline Sedang & $\geq 10.4-13.6$ & 3 & $11.11 \%$ & \multirow{2}{*}{$54.07 \%$} \\
\hline Rendah & $\geq 7.2-10.4$ & 16 & $59.25 \%$ & \\
\hline Sangat Rendah & $\geq 4-7.2$ & 1 & $3.70 \%$ & \\
\hline
\end{tabular}

Berdasarkan tabel 2 persentase pada indikator optimis dalam percaya diri peserta didik sebagian besar berada pada kategori rendah, sedangkan peserta didik lainnya berada pada kategori sangat tinggi, tinggi, sedang, dan sangat rendah. Hal ini ditandai dengan masih banyaknya peserta didik yang merasa bahwa orang lain lebih mampu daripada mereka, dan peserta didik selalu merasa mudah putus asa.

c. Gambaran Percaya Diri Pada Indikator Mandiri

Gambaran percaya diri peserta didik pada indikator mandiri berada pada kategori sangat tinggi sebanyak 1 peserta didik (3.70\%), pada kategori tinggi sebanyak 5 peserta didik (18.51\%), pada kategori sedang sebanyak 1 peserta didik $(3.70 \%)$, pada kategori rendah 
sebanyak 8 peserta didik (29.62\%) dan pada kategori sangat rendah sebanyak 12 peserta didik $(44.44 \%)$. Secara rinci disajikan pada Tabel 13.

Tabel 3. Gambaran Percaya Diri Pada Indikator Mandiri

\begin{tabular}{|c|c|c|c|c|}
\hline Kategori & Interval & Frekuensi & Persentase & Presentase \\
\hline Sangat Tinggi & $\geq 16.8-20$ & 1 & $3.70 \%$ & \\
\hline Tinggi & $\geq 13.6-16.8$ & 5 & $18.51 \%$ & \\
\hline Sedang & $\geq 10.4-13.6$ & 1 & $3.70 \%$ & \multirow{2}{*}{$48.33 \%$} \\
\hline Rendah & $\geq 7.2-10.4$ & 8 & $29.62 \%$ & \\
\hline Sangat Rendah & $\geq 4-7.2$ & 12 & $44.44 \%$ & \\
\hline
\end{tabular}

Berdasarkan tabel 3 persentase pada indikator mandiri dalam percaya diri peserta didik sebagian besar berada pada kategori sangat rendah, sedangkan peserta didik lainnya berada pada kategori sangat tinggi, tinggi, sedang, dan rendah. Tingkat rasa percaya diri peserta didik masih cenderung sangat rendah yang terlihat dari perilaku yang masih bergantung kepada orang lain, dan malu apabila tampil sendirian. PelaksanaanKonseling Puisi Sebagai Media Bimbingan Dan Konseling Dalam Meningkatkan Rasa Percaya Diri Peserta DidikKelas VII SMPN 24 Bandar Lampung Tahun Ajaran 2015/2016.

Pelaksanaan penelitian ini menggunakan layanan bimbingan kelompok dengan konseling puisi sebagai media bimbingan dan konseling dilakukan pada anggota kelompok eksperimen. Kegiatan tersebut dilaksanakan di ruang BK SMPN 24 Bandar Lampung. Pretest diberikan pada hari senin, 23 Mei 2016 kepada seluruh peserta didik kelas VII SMPN 24 Bandar Lampung yang tergabung pada kelompok eksperimen dan kelompok kontrol dalam waktu yang bersamaan.

Pada tahap ini bertujuan untuk membina hubungan baik diawal pertemuan dengan peserta didik, serta memberikan pengarahan tentang penelitian yang akan dilakukan tentang efektivitas konseling puisi serta menggali informasi terkait sikap percaya diri peserta didik dalam kehidupan sehari-hari. Hasil pelaksanaan pretest dapat dikatakan cukup lancar hal ini dapat dilihat dari seluruh peserta didik yang bersedia untuk mengisi instrumen penelitian yang dapat terisi sesuai dengan petunjuk pengisian. Kegiatan pretest dilaksanakan selama \pm 30 menit.

Kelompok eksperimen merupakan kelompok yang akan diberikan perlakuan menggunakan bimbingan kelompok dengan konseling puisi sebagai media bimbingan konseling sedangkan kelompok kontrol tidak diberikan perlakuan menggunakan bimbingan kelompok dengan konseling puisi sebagai media bimbingan konseling namun tetap dikontrol perkembangannya. Pelaksanaan bimbingan kelompok tersebut dilaksanakan dari tanggal 23 Mei-15 Juni 2016 dengan topik pembahasan yang berbeda pada tiap pertemuannya. Hasil Uji Efektivitas Konseling Puisi Sebagai Media Bimbingan Dan Konseling Dalam Meningkatkan Rasa Percaya Diri Peserta Didik Kelas VII SMPN 24 Bandar Lampung Tahun Ajaran 2015/2016

Efektifitas konseling puisi sebagai media bimbingan dan konseling dalam meningkatkan rasa percaya diri peserta didik dapat dilihat dari perbandingan hasil gain score pada kelompok eksperimen dan kelompok kontrol sebelum dan sesudah pelaksanaan layanan konseling puisi. Sebelum dilakukan perbandingan gain score, terlebih dahulu dilakukan uji $\mathrm{t}$ untuk mengetahui pengaruhkonseling puisi sebagai media bimbingan dan konseling dalam meningkatkan rasa percaya diri peserta didik.

Hasil uji efektivitas konseling puisi sebagai media bimbingan dan konseling dalam meningkatan rasa percaya diri peserta didik pada indikator mandiri adalah sebagai berikut: 
Tabel 4. Hasil Uji t Independen Percaya Diri Peserta Didik Pada Kelompok Eksperimen dan Kontrol Pada Indikator Mandiri

\begin{tabular}{|l|c|c|c|l|l|l|l|}
\hline Kelompok & Rata-Rata & Sd & $\begin{array}{c}\text { Perbedaan } \\
\text { Rerata }\end{array}$ & Statistik Uji t & Sig & $\begin{array}{l}\text { Sig.2 } \\
\text { tailed }\end{array}$ & Keterangan \\
\hline Eksperimen & 15.9000 & 0.99443 & \multirow{2}{*}{0.9} & 1.247 & .033 & .234 & Tidak Signifikan \\
\hline Kontrol & 15.0000 & 2.05480 & 0.9 & &
\end{tabular}

Berdasarkan Tabel 4 pada indikator mandiri hasil uji iindependen kelompok eksperimen dan kontrol meningkat namun tidak signifikan, karenamemiliki nilai sig 2. Tailed $>0,05(0,234 \geq 0,05)$. Namun, jika dilihat dari rata-rata, maka pingkatan pada indikator mandiri pada kelompok eksperimen lebih tinggi dibandingkan kelompok kontrol hal ini menunjukkan bahwa penerapan konseling puisi sebagai media bimbingan dan konseling pada kelompok eksperimen lebih efektif dalam meningkatkan kemandirian peserta didik. Peningkatan indikator mandiri peserta didik terlihat pada gambar berikut ini.

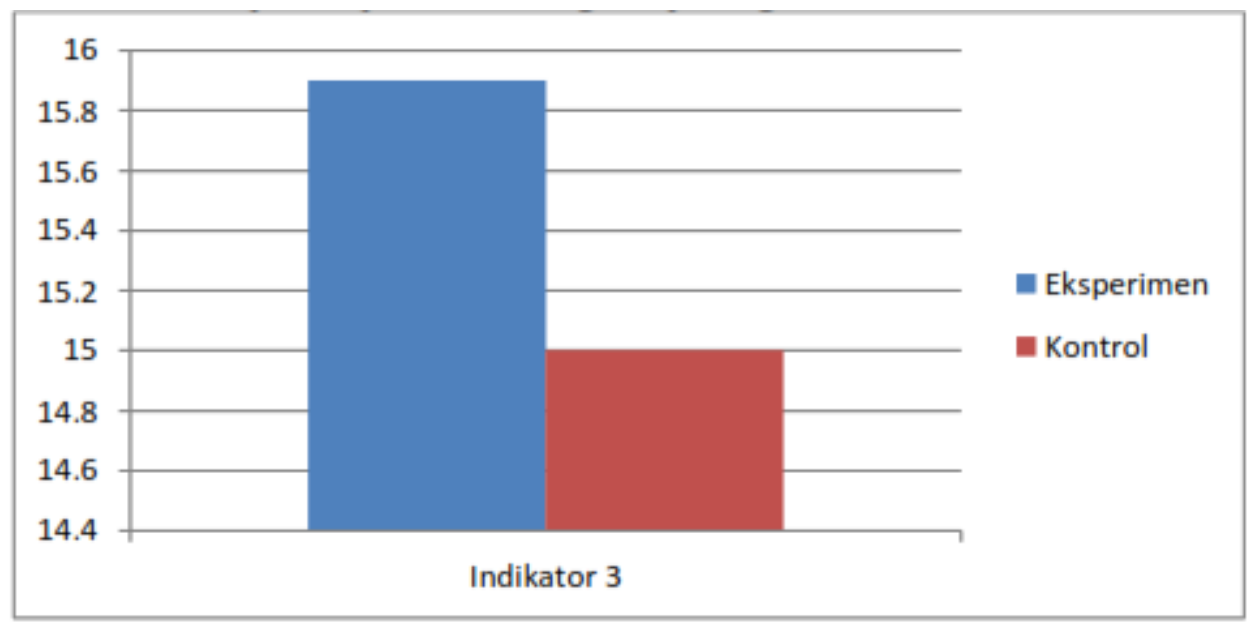

Gambar 1. Peningkatkan kemandirian peserta didik

Pada Gambar 1 penelitian yang telah dilakukan menunjukkan bahwa percaya diri peserta didik di SMPN 24 Bandar Lampung Tahun Ajaran 2015/2016, semua peserta didik yang tidak tampil saat pelombaan membaca puisi dan stand up comedy berada pada kategori rendah. Peserta didik yang tidak percaya diri kurang percaya pada kemampuannya, hal ini yang menyebabkan peserta didik sering menutup diri mereka terhadap dunia luar yang lebih luas. Tanpa kepercayaan diri, peserta didik memiliki resiko kegagalan ataupun kurang optimal dalam mengerjakan tugas-tugasnya. Berbanding terbalik dengan peserta didik yang memiliki kepercayaan diri tinggi. Mereka cenderung berani tampil bahkan tanpa persiapan apapun dan tanpa memikirkan hasilnya.

Ketika peserta didik tidak percaya diri maka akan muncul perasaan malu, mider, dan sungkan. Hal tersebut akan dimanifestasikan dalam sebuah tingkah laku yang kurang wajar atau menyimpang, seperti rendah diri, terisolir, bahkan prestasi belajar yang rendah. Hal ini sesuai dengan pendapat Septi Rahayu Purwanti dalam penelitiannya menyatakan bahwa tidak semua peserta didik memiliki rasa percaya diri yang tinggi, perasaan minder, malu, dan sungkan menjadi kendala bagi peserta didik dalam menjalani proses belajarnya di sekolah maupun di lingkungannya. Peserta didik yang selalu beranggapan bahwa dirinya tidak memiliki kemampuan, merasa dirinya tidak berharga, merupakan gambaran dari peserta didik yang mempunyai masalah kepercayaan diri. Hal ini dapat dimanifestasikan dalam bentuk 
tingkah laku yang kurang wajar atau menyimpang, seperti rendah diri, terisolir, bahkan prestasi belajar yang rendah.

Oleh karena itu dalam penelitian ini peneliti ingin membantu peserta didik untuk meningkatkan rasa percaya dirinya terutama pada saat ingin tampil didepan umum yang berada pada kategori rendah dengan mengunakan konseling puisi sebagai media bimbingan dan konseling, agar peserta didik dapat memiliki rasa percaya diri yang akan berpengaruh pada perkembangan keterampilan dan kemandirian serta membuat peserta didik dapat bersosialisasi dengan baik (pandai bergaul). Efektivitas Konseling Puisi Sebagai Media Bimbingan Dan Konseli Dalam Meningkatkan Rasa Percaya Diri Peserta Didik Kekas VII SMPN 24 Bandar Lampung Tahun Ajaran 2015/2016

ciri-ciri pribadi seseorang yang memiliki sikap percaya diri diantaranya bisa menghargai usahanya sendiri, dan berani menyampaikan pendapat. ng b. Indikator Optimis Berdasarkan hasil analisis data

menunjukkan bahwa terdapat perbedaan setiap indikator antara kelompok eksperimen yang mendapatkan perlakuan menggunakan layanan bimbingan kelompok dengan konseling puisi sebagai media bimbingan dan konseling dan kelompok kontrol yang tidak mendapat perlakuan menggunakanlayanan bimbingan kelompok dengan konseling puisi sebagai media bimbingan dan konseling. Perbedaan setiap indikator tersebut adalah sebagai berikut:

a. Indikator Kemauan dan Usaha

Berdasarkan penyebaran angket percaya diri pada kelompok eksperimen dan kelompok kontrol, keduanya mengalami peningkatan. Kelompok eksperimen meningkat dari $50.55 \%$ menjadi $84 \%$. Sedangkan pada kelompok kontrol meningkat dari $40.5 \%$ menjadi $73 \%$. Namun, kelompok eksperimen lebih besar peningkatannya dibandingkan dengan kelompok kontrol $(84 \%>73 \%)$. Maka dapat dikatakan bahwa layanan bimbingan kelompok dengan konseling puisi sebagai media bimbingan dan konseling lebih efektif untuk meningkatkan rasa percaya diri peserta didik dibandingkan dengan bimbingan kelompok tanpa konseling puisi sebagai media bimbingan dan konseling. Pada indikator ini, peserta didik sudah terlihat percaya diri seperti memberanikan diri untuk bertanya kepada guru ketika ada mata pelajaran yang tidak dimengerti, berani menyampaikan pendapat, dan mulai berani untuk mengerjakan soal didepan kelas. Hal ini sesuai dengan pendapat Syaifullah dalam Dewi tentang ciri-ciri pribadi seseorang yang memiliksikap percaya diri diantaranya bisamenghargai usahanya sendiri, dan beranmenyampaikan pendapat.

b. Indikator Optimis

Berdasarkan penyebaran angket percaya diri pada kelompok eksperimen dan kelompok kontrol, keduanya mengalami peningkatan. Kelompok eksperimen meningkat dari $47 \%$ menjadi $84 \%$. Sedangkan pada kelompok kontrol meningkat dari $43 \%$ menjadi $78.5 \%$. Namun, kelompok eksperimen lebih besar peningkatannya dibandingkan dengan kelompok kontrol $(84 \%>78.5 \%)$. Maka dapat dikatakan bahwa layanan bimbingan kelompok dengan konseling puisi sebagai media bimbingan dan konseling lebih efektif untuk meningkatkan rasa percaya diri peserta didik dibandingkan dengan bimbingan kelompok tanpa konseling puisi sebagai media bimbingan dan konseling. Pada indikator ini, peserta didik sudah terlihat mampu untuk mengerjakan suatu hal dengan baik, dan memiliki keyakinan dalam belajar. Hal ini sesuai dengan pendapat Enung Fatimah tentang beberapa ciri atau karakteristik individu yang memiliki sikap percaya diri yaitu percaya akan kompetensi/kemampuan diri, hingga tidak membutuhkan pujian, pengakuan, penerimaan, ataupun hormat dari orang lain. Tidak mudah menyerah serta tidak tergantung mengharapkan bantuan orang lain. 


\section{c. Indikator Mandiri}

Berdasarkan penyebaran angket percaya diri pada kelompok eksperimen dan kelompok kontrol, keduanya mengalami peningkatan. Kelompok eksperimen meningkat dari $41.5 \%$ menjadi $79.5 \%$. Sedangkan pada kelompok kontrol meningkat dari $36.5 \%$ menjadi $75 \%$. Namun, kelompok eksperimen lebih besar peningkatannya dibandingkan dengan kelompok kontrol $(79.5 \%>75 \%)$. Maka dapat dikatakan bahwa layanan bimbingan kelompok dengan konseling puisi sebagai mediabimbingan dan konseling lebih efektif untuk meningkatkan rasa percaya diri peserta didik dibandingkan dengan bimbingan kelompok tanpa konseling puisi sebagai media bimbingan dan konseling. Pada indikator ini, peserta didik sudah berusaha untuk bersikap tenang dalam menyelesaikan masalah dan berusaha untuk menyelesaikan tugas tanpa bantuan orang lain. Percaya diri adalah keyakinan bahwa orang mempunyai kemampuan untuk melakukan sesuatu untuk mencapai tujuan tertentu. Percaya diri juga merupakan keyakinan orang atas kemampuannya untuk menghasilkan level-level pelaksanaan yang memengaruhi kejadian-kejadian yang memengaruhi kehidupan mereka.

d. Indikator Tidak Mudah Menyerah

Berdasarkan penyebaran angket percaya diri pada kelompok eksperimen dan kelompok kontrol, keduanya mengalami peningkatan. Kelompok eksperimen meningkat dari $46.5 \%$ menjadi $81.5 \%$. Sedangkan pada kelompok kontrol meningkat dari $40.5 \%$ menjadi $73.5 \%$. Namun, kelompok eksperimen lebih besar peningkatannya dibandingkan dengan kelompok kontrol $(81.5 \%>73.5 \%)$. Maka dapat dikatakan bahwa layanan bimbingan kelompok dengan konseling puisi sebagai media bimbingan dan konseling lebih efektif untuk meningkatkan rasa percaya diri peserta didik dibandingkan dengan bimbingan kelompok tanpa konseling puisi sebagai media bimbingan dan konseling. Pada indikator ini, pesereta didik sudah terlihat bahwasanya sebuah permasalahan pasti ada jalan keluarnya dan peserta didik mulai menyukai tantangan. Hal tersebut sesuai dengan pendapat Syaifullah dalam Dewi tentang ciri-ciri pribadi seseorang yang memiliki sikap percaya diri yaitu tidak mudah mengalami rasa putus asa. Pribadi yang percaya diri akan selalu antusias dalam melakukan suatu tindakan, memiliki tekad, tekun dan pantang menyerah.

e. Indikator Mampu Menyesuaikan Diri

Berdasarkan penyebaran angket percaya diri pada kelompok eksperimen dan kelompok kontrol, keduanya mengalami peningkatan. Kelompok eksperimen meningkat dari $42.67 \%$ menjadi $74.67 \%$. Sedangkan pada kelompok kontrol meningkat dari $47.33 \%$ menjadi $68.67 \%$. Namun, kelompok eksperimen lebih besar peningkatannya dibandingkan dengan kelompok kontrol $(74.67 \%>68.6 \%)$. Maka dapat dikatakan bahwa layanan bimbingan kelompok dengan konseling puisi sebagai media bimbingan dan konseling lebih efektif untuk meningkatkan rasa percaya diri peserta didik dibandingkan dengan bimbingan kelompok tanpa konseling puisi sebagai media bimbingan dan konseling. Pada indikator ini, peserta didik sudah dapat bergaul dengan teman-temannya yang lain. Dengan percaya diri, kita sadar akan eksistensi diri, dan percaya diri itu penting dalam kaitannya dengan percaya pada orang lain yang persetujuannya menjadi dasar perasaan kita akan identitas.

f. Indikator Memiliki Dan Memanfaatkan Kelebihan.

Berdasarkan penyebaran angket percaya diri pada kelompok eksperimen dan kelompok kontrol, keduanya mengalami peningkatan. Kelompok eksperimen meningkat dari $45.33 \%$ menjadi $86 \%$. Sedangkan pada kelompok kontrol meningkat dari $45.33 \%$ menjadi $71.33 \%$. Namun, kelompok eksperimen lebih besar peningkatannya dibandingkan dengan kelompok kontrol $(86 \%>71.33 \%)$. Maka dapat dikatakan bahwa layanan bimbingan kelompok dengan konseling puisi sebagai media bimbingan dan konseling lebih efektif untuk meningkatkan rasa percaya diri peserta didik dibandingkan dengan bimbingan kelompok tanpa konseling puisi sebagaimedia bimbingan dan konseling.Pada indikator ini, peserta didik sudah dapat memahami potensi yang dimiliki dan ingin mengembangkan potensi tersebut. Percaya diri 
adalah keyakinan bahwa orang mempunyai kemampuan untuk memutuskan jalannya suatu tindakan yang dituntut untuk mengurusi situasi-situasi yang dihadapi.

g. Indikator Memiliki Mental dan Fisik Yang Menunjang.

Berdasarkan penyebaran angket percaya diri pada kelompok eksperimen dan kelompok kontrol, keduanya mengalami peningkatan. Kelompok eksperimen meningkat dari $39.33 \%$ menjadi $82 \%$. Sedangkan pada kelompok kontrol meningkat dari $39.33 \%$ menjadi $64 \%$. Namun, kelompok eksperimen lebih besar peningkatannya dibandingkan dengan kelompok kontrol $(82 \%>64 \%)$. Maka dapat dikatakan bahwa layanan bimbingan kelompok dengan konseling puisi sebagai media bimbingan dan konseling lebih efektif untuk meningkatkan rasa percaya diri peserta didik dibandingkan dengan bimbingan kelompok tanpa konseling puisi sebagai media bimbingan dan konseling. Pada indikator ini, peserta didik sudah terlihat bahagia dan menerima apa yang menjadi anugrah dari Tuhan Yang Maha Esa. Percaya diri pada dasarnya merupakan suatu keyakinan untuk menjalani kehidupan, mempertimbangkan pilihan dan membuat keputusan sendiri pada diri sendiri bahwa ia mampu untuk melakukan sesuatu. Artinya keyakinan dan percaya diri hanya timbul pada saat seseorang mengerjakan sesuatu yang memang mampu dilakukannya. Pada dasarnya seseorang merasa puas pada dirinya sendiri hanya pada saat melakukan suatu kegiatan, pekerjaan atau menyalurkan kemampuannya. Banyak hal yang dapat dilakukan dan banyak juga kemampuan yang dapat dikuasai seseorang dalam hidupnya.

Setelah melaksanakan kegiatan layanan bimbingan kelompok dengan konseling puisi sebagai media bimbingan dan konselingyang dilakukan sebanyak 6 kali pada kelompok eksperimen dan bimbingan kelompok tanpa konseling puisi sebanyak 2 kali pada kelompok kontrol, terdapat beberapa kesan bagi peneliti bahwa peneliti merasa senang ketika melihat anggota kelompok dapat merubah pola fikir mereka tentang kelebihan masing-masing. Anggota kelompok merasakan banyak manfaat yang diambil setelah pelaksanaan bimbingan kelompok. anggota kelompok menyadari bahwa bersyukur itu lebih penting sehingga lebih bisa menghargai diri sendiri dan yakin akan kemampunan yang dimiliki sehingga dapat percaya diri.

Tercapainya tujuan penelitian mulai terlihat dimana suasana kelompok tercipta dengan baik, sehingga anggota kelompok antusias mengungkapkan pendapatnya, pengalamannya, dan ide-ide yang mereka punya. Anggota kelompok merasa senang ketika semua anggota kelompok saling menghargai satu sama lainnya. Selain itusetiap anggota kelompok terlihat senang ketika anggota kelompok yang lain memberikan penguatan. Hal ini terlihat dari perkembangan hasil pengisian laiseg dari setiap pertemuan. Sehingga anggota kelompok lebih percaya diri dalam memberikan pendapatnya.

\section{Simpulan dan Saran}

Berdasarkan hasil penelitian "Efektivitas Konseling Puisi Sebagai Media Bimbingan dan

Konseling Dalam Meningkatkan Rasa Percaya Diri Peserta Didik Kelas VII SMPN 24

Bandar Lampung Tahun Ajaran 2015/2016", maka diperoleh simpulan sebagai berikut:

1. Tingkat percaya diri peserta didik pada kelompok eksperimen dapat dilihat dari hasil pretest yangmenunjukkan persentase rata-ratasebesar $44.96 \%$. Setelah mendapatkan treatment menggunakankonseling puisi sebagai media bimbingan dan konseling, tingkat percaya diri peserta didik mengalami peningkatan. Hasil posttest menunjukkan persentase ratata-rata peningkat sebesar $81.68 \%$.

2. Sedangkan pada kelompok kontrol sama sama mengalami peningkatan. Hasil pretest menunjukkan presentase rata-rata sebesar $41.5 \%$. Setelah mengikuti kegiatan konseling puisi, tingkat percaya diri peserta didik pada kelompok kontrol mengalami peningkatan juga. Terlihat dari hasil posttest yang menunjukkan presentasi rata-rata sebesar $72.48 \%$. Walaupun kedua kelompok mengalami peningkatan, namun kelompok eksperimen lebih 
meningkat dibandingkan kelompok kontrol. Hal tersebut dapat terlihat dari hasil posttest kelompok eksperimen lebih besar dibandingkan kelompok kontrol $(81.68 \%>72.48)$ yang menunjukkan bahwasanya konseling puisi sebagai media bimbingan dan konseling efektif digunakan dalam meningkatkan rasa percaya diri peserta didik.

2. Peningkatan percaya diri pesertadidik dengan konseling puisi sebagai media bimbingan dan konseling ini terbukti dari hasil uji t. Berdasarkan hasil perhitungan pengujian diperoleh thitung 3,939 pada derajat kebebasan (df) 18 kemudian dibandingkan dengan tabel 0,05 $=2,101$, maka thitung $\geq$ tabel $(3,939 \geq 2,101)$ atau nilai sign. (2-tailed) lebih kecil dari nilai kritik $0,005(0.002 \leq 0,005)$. Selain itu didapatkan nilai rata-ratakelompok eksperimen lebih besar dari pada kelompok kontrol $(102.1000 \geq 90.6000)$. Jika dilihat dari nilai ratarata, maka peningkatan rasa percaya diri pada kelompok eksperimen lebih tinggi dibanding dengan kelompok Kontrol. Untuk guru BK, diharapkan dapat memberikan layanan yang ada dalam bimbingan dan konseling terutama layanan bimbingankelompok dengan konseling puisi sebagai media bimbingan dan konseling dalam upaya meningkatkan percaya diri peserta didik. Guru BK juga diharapkan lebih melakukan pendekatan dengan peserta didik agar dapat mengungkap permasalahan peserta didik secara lebih mendalam dan dapat menuntaskan permasalahan peserta didik secara maksimal. Sementara itu, dikarenakan penelitian ini merupakan penelitian terbaru, maka untuk peneliti selanjutnya diharapkan agar lebih mendalami lagi mengenai konseling puisi. Jika diperlukan, lakukanlah uji konstruk terhadap ahli sastra dan lampirkanlah mengenai hasil uji konstruk tersebut.

\section{Daftar Pustaka}

Abdurrahman, Fatoni. Metodologi Penelitian dan Teknik Penyusunan Skripsi. Jakarta: Rineka Cipta. 2011.

A. Said Hasan Basri. Peran Media Dalam Layanan Bimbingan dan Konseling Islam di Sekolah, Jurnal Dakwah. Yogyakarta: UIN Sunan Kalijaga. 2010.

Al-Quran dan Terjemahannya. Departemen Agama RI. Bandung: Syaamil Qur'an. 2007.

Anwar, Sutoyo. Pemahaman Individu. Yogyakarta: Pustaka Pelajar.2012.

Arsyad, Azhar. Media Pembelajaran. Jakarta: PT Raja Grafindo Persada. 2015.

Gladding, Samuel T. The Creative Arts In Counseling. USA: American Counseling Associations.2011.

Hasanah, Nur. Pengaruh Bimbingan Kelompok Teknik Lingkaran (Round) Terhadap Percaya Diri Siswa Kelas VIII Di SMP Negeri 2 Gorontalo. (Skripsi Program Sarjana Pendidikan Universitas Negeri Gorontalo)

Illarezkiwanda, Dunia BK-Bimbingan dan Konseling. [on-line], tersedia di: http://illarezkiwanda.blogspot.co.id/ [3 Maret 2016]

Ivanne's Gallery, Peranan Percaya Diri Dalam Pembelajaran. [On-Line], tersedia di: http://vanneisblessing.blogspot.co.id/2012/02/peranan-percaya-diri-dalampembelajaran.html [31 Januari 2016]

John Creswell. Research Design Pendekatan Kualitatif, Kuantitatif, dan Mixed. Yogyakarta: Pustaka Pelajar. 2013.

Maharani, Laila. Konseling Puisi:Konseling Diri Melalui Media Puisi. Bandar Lampung: CV. Teams Barokah. 2014. 
Maya, Citraan Dalam Puisi, [On-Line], tersedia di: https://kelasmayaku.wordpress.com/2011/02/09/citraan-dalam-puisi/ [21 Maret 2016]

Muhibbinsyah. Psikologi Pendidikan. Bandung: PT Remaja Rosdakarya. 2010.

Mustari, Mohamad. Nilai Karakter Refleksi Untuk Pendidikan. Jakarta: PT Raja Grafindo Persada. 2014.

Nursalim, Mochamad. Media Bimbingan dan Konseling. Jakarta: Unesa university press.2010.

Prayitno. Dasar-Dasar Bimbingan dan Konseling. Jakarta: Rineka Cipta. 2008.

Purwanti, septi rahayu. "mengatasi masalah kepercayaan diri siswa melalui layanan konseling kelompok pada siswa kelas VIII F SMP Negeri 2 Karangpucung kabupaten cilacap". (Skripsi Program Sarjana Pendidikan Universitas Negeri Semarang, Semarang, 2013)

Rostina Sundayana. Statistika Penelitian Pendidkan. Bandung: Alfabeta.2014.

Sarwono, Sarlito W. Dan Eko A. Meinamo. Psikologi Sosial. Depok: Salemba Humanika. 2009.

Sarwitto, Putra, Ciri-Ciri Orang Percaya Diri, [On-Line], Tersedia di: http://wargasawitto.blogspot.co.id/2013/02/ciri-ciri-orang-percaya-diri.html [30 Januari 2016]

Sudjana. Metode Statistika. Bandung: Tarsito.2005.

Sugiyono. Metode Penelitian Kuantitatif Kualitatif Dan R\&D. Bandung: Alfabeta. 2013.

Suhardita, Kadek. "Efektivitas Penggunaan Teknik Permainan Dalam Bimbingan Kelompok Untuk Meningkatkan Percaya Diri Siswa”. Edisi Khusus No.1. Agustus 2013

Supriatna, Mamat. Bimbingan dan Konseling Berbasis Kompetensi. Jakarta: Rajawali Pers. 2011.

Tumigar, Sriwahyuni. "Peningkatan Keterampilan Membaca Puisi Dengan Model Amati, Tiru, Modivikasi Menggunakan Media Video Pembacaan Puisi Pada Siswa Kelas VII A SMPN 1 Sambong Kabupaten Blora". Skripsi (Semarang, UNS, 2014)

Undana. Pelaksanaan Kegiatan, [On-Line], tersedia di: http://bimbingankonselingundana.blogspot.co.id/p/pelaksanaan-kegiatan.html [27 Januari 2016]

Utama, Wahyu Puja. "efektivitas Pemberian Layanan Bibliokonseling Untuk Meningkatkan Percaya Diri Siswa Kelas IX C di SMPLB Krida Utama 2 Loceret Tahun 2014/2015”, Skripsi (Kediri, Universitas Nusantara PGRI Kediri, 2014)

Wayan, Nurkencana. Pemahaman Individu. Surabaya: Usaha Nasional. 2010.

Widoyo, Eko Putra. Penelitian Hasil Pembelajaran di Sekolah. Yogyakarta: Pustaka Pelajar. 2014

Wikipedia Bahasa Indonesia. Puisi, [on-line], tersedia di: https://id.m.wikipedia.org/wiki/Kategori:Puisi [15 Januari 2016] 
